\title{
Morphological Changes in a Susceptible Strain of Streptococcus pyogenes Treated with Streptocin A
}

\author{
By J. R. TAGG,* E. A. PIHL AND A. R. MCGIVEN $\dagger$ \\ Department of Pathology, Monash University Medical School, \\ Melbourne, Australia
}

(Received 22 June 1973)

The production of bacteriocins is a property common to various strains of most bacterial species (Reeves, I965). Bacteriocin-like inhibition associated with group A streptococcal cultures has been described (Kuttner, I966; Overturf \& Mortimer, 1970) and recently our laboratory has reported the isolation of a group A streptococcal bacteriocin, streptocin A, from cultures of Streptococcus pyogenes strain FF22 (Tagg, Read \& McGiven, I97I). This bacteriocin was shown to be active against a wide range of different Gram-positive organisms but had no detectable action against Gram-negative species. Certain strains of Staphylococcus aureus have also been shown to produce bacteriocins (Dajani \& Wannamaker, 1969; Gagliano \& Hinsdill, 1970) with a range of activity and physical properties similar to those of streptocin A. The present report gives an account of investigations of the morphological changes produced in a susceptible strain of $S$. pyogenes following treatment with streptocin A.

The procedures adopted for the purification of streptocin A have been described in detail elsewhere (Tagg, Read \& McGiven, 1973). One $\mathrm{ml}$ of a preparation of streptocin A (titre 8) was mixed with $\mathrm{I} \mathrm{ml}$ (containing $\mathrm{I} \times \mathrm{IO}^{9}$ colony forming units) of a logarithmic phase Todd Hewitt broth culture of strain $\mathrm{FF}_{3} 8$, washed twice in phosphate-buffered saline $(\mathrm{pH} 6.5)$. Streptocin A was shown to have a bactericidal effect on the susceptible streptococcus. Viability tests on samples taken at various times from mixtures of the streptocin A preparation (titre 8 ) and washed strain FF3 8 showed that there was an exponential decline in viability from $2 \times 10^{6}$ colony forming units $/ \mathrm{ml}$ to no detectable viable organisms after $4 \mathrm{~h}$ at $37{ }^{\circ} \mathrm{C}$. Control preparations of strain FF 38 in phosphate-buffered saline (pH 6.5) showed no appreciable decrease in viability during a $4 \mathrm{~h}$ test period at $37^{\circ} \mathrm{C}$. Comparison of the change in extinction values at $600 \mathrm{~nm}$ of the test and control suspensions indicated no differences over $6 \mathrm{~h}$ and, hence, that the bacteriocin-treated organisms had not undergone any lysis.

Morphological changes produced in susceptible organisms were studied by electron microscopy of unfixed whole mounts, prepared by critical point drying using a previously described procedure (Cox, Pihl, Read \& Nairn, 1972). Ultrathin sections were also prepared, essentially according to the method of Luft (I966), with fixation in $0.15 \%(\mathrm{w} / \mathrm{v})$ ruthenium red and $0.1 \mathrm{M}$-cacodylate buffer $(\mathrm{pH} 7 \cdot 6)$ containing $3 \%(\mathrm{w} / \mathrm{v})$ glutaraldehyde, followed by post-fixation in $\mathrm{I} \%(\mathrm{w} / \mathrm{v})$ osmium tetroxide. Cultures of the sensitive streptococcus (strain $\mathrm{FF}_{3} 8$ ) were examined at time zero, 30 and $\mathrm{I} 20$ min after mixing with streptocin $\mathrm{A}$.

Normal untreated organisms had the appearance shown in Fig. I $(a)$. The individual cocci, arranged in chains, each had a roughly circular outline and the cell contents appeared homogeneous in whole-mount preparations.

* Present address: Department of Pediatrics, University of Minnesota, Minneapolis, Minnesota 55455, U.S.A.

$\dagger$ Present address: Department of Pathology, Christchurch Clinical School, Christchurch, New Zealand. 

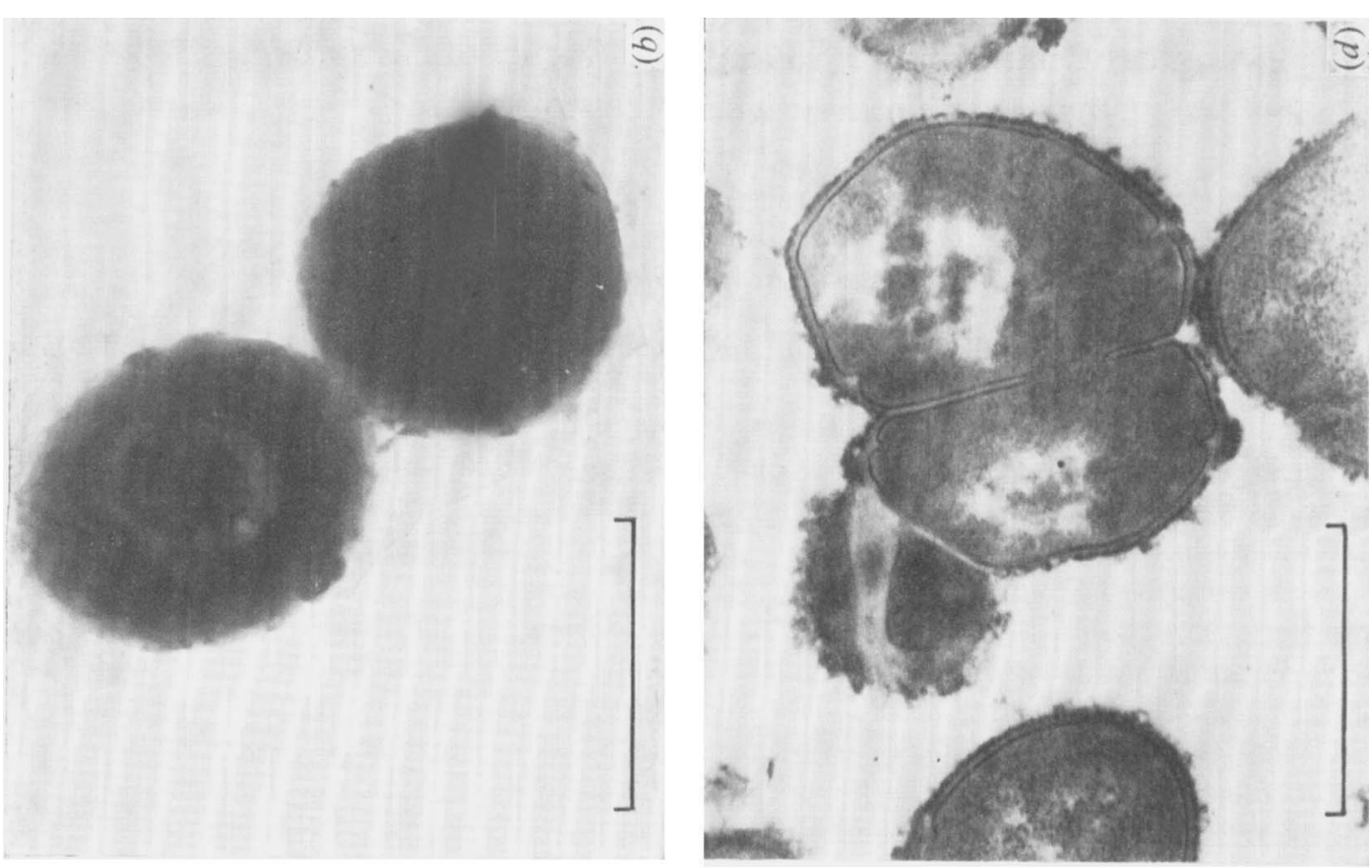

言串焉 总通的 임

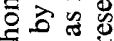

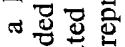

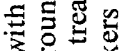
蛋 马灾

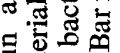
氖完。 를

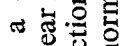
$\Xi \bar{O}$ 고용 总宁吾 预氙焉告 $\infty \stackrel{5}{ }$ 迹官 山

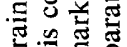
离运 仓ैّ 政 $\stackrel{0}{0}$ ․ㅡ능
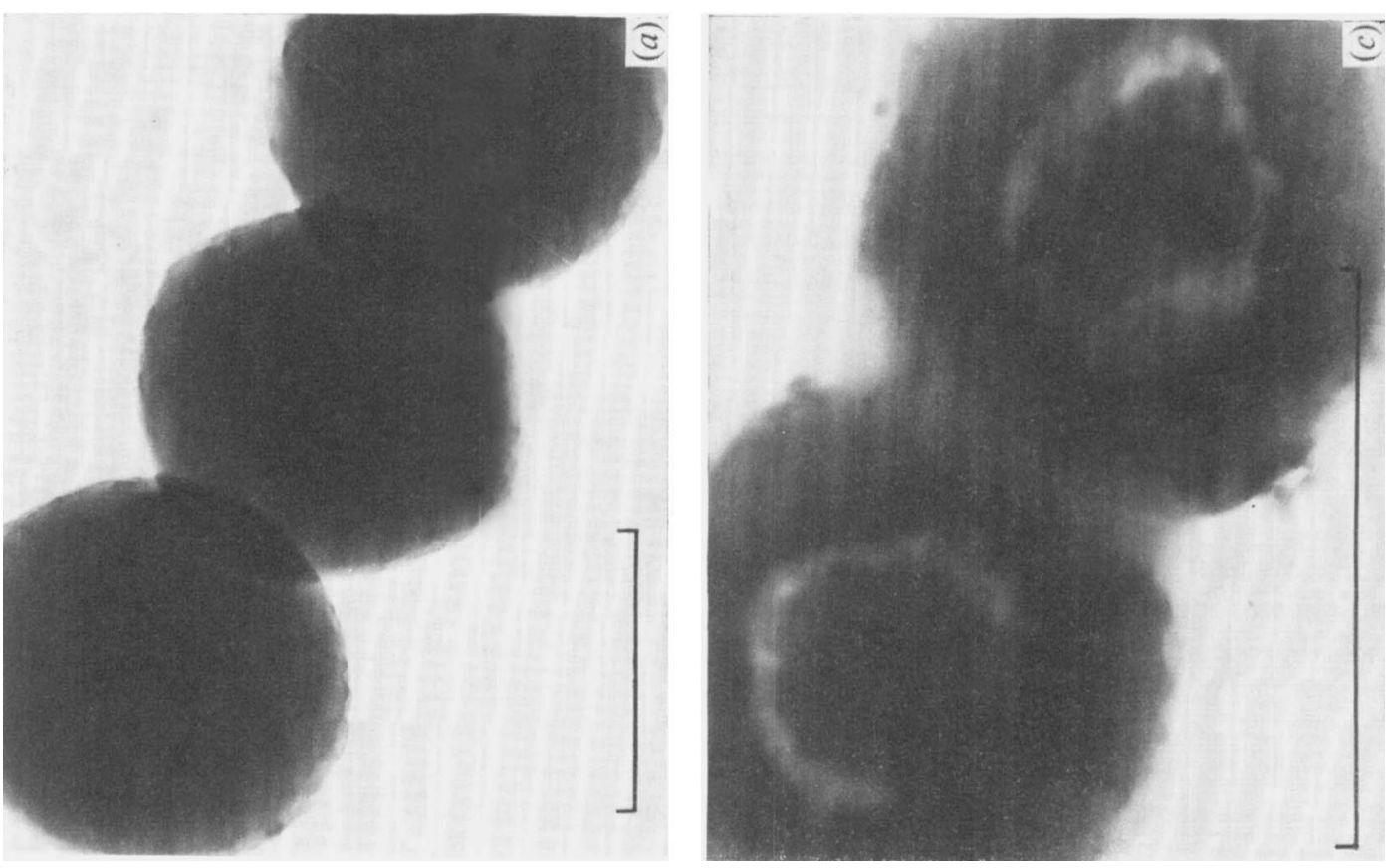

융응

응. 额 돈

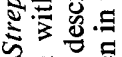
ธี 马्త 용 苋䒠密 声.气 颔

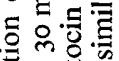

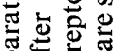
응 娄荥

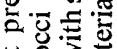
范实苋 응옹을 政 녹을 政. 3 의 (월 $\therefore$

- Э

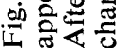


Within 30 min of contact with streptocin A, visible changes had developed within the central portions of some of the cocci (Fig. I $b$ ), apparently consisting of a condensation of the nuclear material with an accompanying increase in the perinuclear space. After $180 \mathrm{~min}$ nearly all appeared to be affected (Fig. I $c$ ). Ultrathin sections of such organisms (Fig. I $d$ ) showed changes consistent with those observed in whole mount preparations. There was no apparent change in the morphological appearance of the walls.

The structural changes produced by streptocin A in a susceptible group A streptococcus seem similar to the changes observed following treatment of a susceptible streptococcus with a staphylococcal bacteriocin (Clawson \& Dajani, 1970). There have been only a few other reports of ultrastructural changes in bacteria treated with bacteriocins. The observed changes have been produced by colicins (Beppu \& Arima, I97I), pyocins (Ohnishi, Takade \& Takeya, 197I) and also boticins (Ellison, Mattern \& Daniel, 1971) and are not unlike those described in the present study. Recently it has been shown that streptocin $\mathrm{A}$ is also toxic for mammalian heart cells, possibly due to a sharing of specific receptors between sensitive micro-organisms and the heart cell membrane (Tagg, I972). Our present studies are being directed towards an examination of the ultrastructural changes in heart muscle cells following treatment with purified streptocin A. Such investigations may provide evidence clarifying the possible role of streptocin A in the pathogenesis of rheumatic carditis (Tagg \& McGiven, 1972).

\section{REFERENCES}

Beppu, T. \& Arima, K. (I97I). Properties of the colicin E2-induced degradation of deoxyribonucleic acid in Escherichia coli. Journal of Biochemistry 70, 263-27I.

Clawson, C. C. \& Dajanl, A. S. (1970). Effect of bactericidal substance from Staphylococcus aureus on group A streptococci. II. Structural alterations. Infection and Immunity I, 49I-498.

Cox, J. C., Pinl, E., Read, R. S. D. \& NaIRN, R. C. (I972). Rapid localization of bacterial surface antigens by whole-mount immunoperoxidase technique. Journal of General Microbiology 7o, 385-389.

Dajani, A.S. \& Wannamaker, L. W. (1969). Demonstration of a bactericidal substance against betahemolytic streptococci in supernatant fluids of staphylococcal cultures. Journal of Bacteriology 97, 985-99I.

Ellison, J. S., Mattern, C. F. T. \& Daniel, W. A. (I97I). Structural changes in Clostridium botulinium type $\mathrm{E}$ after treatment with boticin $\mathrm{S}_{51}$. Journal of Bacteriology 108, 526-534.

Gagliano, V. J. \& HinsDill, R. D. (1970). Characterization of a Staphylococcus aureus bacteriocin. Journal of Bacteriology 104, II $7-125$.

KutTnER, A. G. (1966). Production of bacteriocines by group A streptococci with special reference to the nephritogenic types. Journal of Experimental Medicine 124, 279-29I.

LuFT, J. H. (1966). Fine structure of capillary and endocapillary layer as revealed by ruthenium red. Federation Proceedings 25, $1773-1783$.

Ohnishi, Y., TAKade, A. \& TAKeYA, K. (I971). Morphological changes in Pseudomonas aeruginosa treated with rod-shaped pyocin 28. Japanese Journal of Microbiology 15, 20I-205.

Overturf, G. D. \& Mortimer, E. A. (1970). Studies of the relationship between the production of bacteriocines by Group A streptococci and acute glomerulonephritis. Journal of Experimental Medicine 132, 694-70I.

ReEves, P. (1965). The bacteriocins. Bacteriological Reviews 29, $24-45$.

TAGG, J. R. (1972). Group A streptococci and rheumatic fever. Ph.D. Thesis, Monash University,

TAGG, J. R. \& MCGIven, A. R. (I972). Some possible autoimmune mechanisms in rheumatic carditis. The Lancet ii, 686-688.

TAGG, J. R., READ, R. S. D. \& MCGIVEN, A. R. (1971). Bacteriocin production by group A streptococci. Pathology 3, 277-278.

TAGG, J. R., ReAD, R. S. D. \& MCGiven, A. R. (1973). Bacteriocin of a group A streptococcus. Partial purification and properties. Antimicrobial Agents and Chemotherapy (in the Press). 